This is an electronic reprint of the original article. This reprint may differ from the original in pagination and typographic detail.

Author(s): Laihonen, Petteri

Title: Beware of the dog! Private linguistic landscapes in two 'Hungarian' villages in SouthWest Slovakia

Year: $\quad 2016$

Version:

Please cite the original version:

Laihonen, P. (2016). Beware of the dog! Private linguistic landscapes in two 'Hungarian' villages in South-West Slovakia. Language Policy, 15 (4), 373-391. doi:10.1007/s10993-015-9358-y. See also http://rdcu.be/kNut

All material supplied via JYX is protected by copyright and other intellectual property rights, and duplication or sale of all or part of any of the repository collections is not permitted, except that material may be duplicated by you for your research use or educational purposes in electronic or print form. You must obtain permission for any other use. Electronic or print copies may not be offered, whether for sale or otherwise to anyone who is not an authorised user. 


\title{
Beware of the Dog! Private Linguistic Landscapes in Two 'Hungarian’ Villages in
}

\section{South-West Slovakia}

\section{Petteri Laihonen}

\begin{abstract}
This study demonstrates how a single type of sign can be connected to language policy on a larger scale. Focusing on the relationship between language policy and language ideologies, I investigate the private Linguistic Landscape (LL) of Hungarians living in two villages in Slovakia. Through an examination of 'beware of the dog' signs, it is shown how such signs can be indicative of different language policies. In Slovakia, the Hungarian public $\mathrm{LL}$ is often referred to as a threat to the state language and public order. This ideology is reflected on the LL so that there are mostly Slovak-only public signs in bilingual and Hungarian dominant villages. The private realm is the only significant area where a certain Hungarian dominance is present. In a bilingual village, Hungarians prefer Slovak in their public signage, while in a village with Hungarian majority people invest on having private Hungarian signs by purchasing them in Hungary as well as through hand-making signs. The counter-normativity of having monolingual Hungarian signs is underlined by several factors. First, the language policy referred to as laws have put an emphasis on warning signs. Secondly, a Hungarian language rights leaflet has elevated 'beware of the dog' signs as normatively bilingual. Thirdly, the context of Slovakia, engaged in nation building disfavors the public use of Hungarian. This paper illustrates the importance of considering ideologies as reflected in private LL in multilingual contexts in transition.
\end{abstract}

Keywords Linguistic Landscape, private domain, simple language management, language ideology, Hungarian language, Slovakia

P. Laihonen ( )

Centre for Applied Language Studies and Department of Languages, University of Jyvaskyla P.O. Box 35, FI-40014 University of Jyvaskyla, Finland email: petteri.laihonen@jyu.fi 


\section{Introduction}

This paper investigates the private Linguistic Landscape (LL) of an historical minority, defined as members of a non-immigrant (autochthonous/indigenous) language community that has become dominated by another language community. Private visual language use is thought to be typical bottom-up, non-commercial activity, which is free of regulation and as a consequence has rarely been studied. However, through an examination of the most frequent private sign type in minority villages, namely, 'beware of the dog' signs, it will be shown, how private signs can be ideologically charged and indicative of different language policies.

For the study of language policy, the LL offers a view of how languages are connected to social structure and hierarchies, and how they are regulated or controlled in public (Shohamy 2006). The LL can be understood in a wider sense as visual language use in general; that is, beyond the official or commercial signage. This paper aims to fill the gap in both language policy and LL studies by investigating how people make language choices in public contexts where they have the most freedom, thus contributing to the dialog on language planning at the local level (Nekvapil 2009).

Language choice is guided by language ideologies, by presumptions we make on the relationship of language use, social order and the speaker (Gal 2006). Shohamy (2006) casts the $\mathrm{LL}$ as a language policy mechanism as it interprets and transmits ideology into language practices. Both dominant ideologies and resistance to them can be included. This means that through the LL authorities construct the prestige of different languages and regulate the hierarchy of elements in the linguistic repertoire of a given society. Furthermore, resistance to dominant ideologies by private individuals is typically displayed in the LL (Shohamy 2006).

According to Nekvapil (2009), simple language management refers to the process where laymen notice a deviation of a norm in everyday language use, evaluate it and may 
adjust their linguistic practices accordingly. Simple management is thus where a change in the norms and language practices typically begins. Blommaert (2013) suggests that private signs in the public space are the first to show change in the LL and society, and may therefore serve as markers of nascent resistance, or pointers to future trends. It may thus also provide a window into language change.

Earlier LL studies mentioned signage by ordinary citizens as a linguistic practice where minorities are allowed to use the language(s) "they favor or are most comfortable in" (Pavlenko 2012: 54). As a category of free choice, private signage has been described as the set of signs that best mirror the inhabitants' ethnolinguistic affiliation in both autonomous (Dal Negro 2009) and minoritized (Shohamy and Ghazaleh-Mahajneh 2012) contexts.

This paper investigates a specific type of private signs. The 'beware of the dog' signs were chosen for several reasons. First, as a brief search on the internet shows, these signs are prevalent and common private signs in the public spaces in many parts of the world. Second, in Southern Slovakia, the area under study, there has been an attempt to regulate the language choice of their inscriptions. In addition, most of the signs in the investigated contexts are new signs, and thus reflect the political, ideological and economic changes of the current era.

This article is structured as follows: after explicating the definition of 'private', the context of the research site, Hungarian villages in Slovakia, is presented in order to contextualize language ideologies made visible through the LL. This is followed by a description of methodology and data. Then findings are presented, and finally the ways the 'beware of the dog' sign can be connected to language policy on a larger scale are discussed.

\section{Defining private}

Signs are indicative of the producer, addressees, message and placement (Scollon and Scollon 2003; Blommaert 2013). The dichotomies of public/private or bottom-up/top-down have been 
widely applied in LL research. One difference between the top-down/bottom-up and the public/private is that the former makes assumptions on the flow, that is, both the producers and addressees of signs, whereas the latter only focuses on producers (Laundry and Bourhis 1997). According to Ben Rafael et al. (2006:10), top-down elements are "used and exhibited by institutional agencies [...] which act under the control of local or central policies". Bottom-up signs are "utilized by individual, associative or corporative actors who enjoy autonomy of action within legal limits". The top-down signs "are expected to reflect a general commitment to the dominant culture while [the bottom-up signs] are designed much more freely according to individual strategies.” (p. 10).

Recent criticism of this dichotomy suggests that it leaves too many borderline cases (Dal Negro 2009), or that it "fails to capture the notion of agency and how it impacts language forms in the LL" (Huebner 2009: 74). Kallen (2009) in turn notices that instead of hierarchical communication, the relationship between producers and viewers of signs is often horizontal, i.e. the idea of a vertical flow is deceptive. In addition, the notions of 'official' (public) or 'private' can seldom be established in a non-ambiguous way (Coupland 2012). Pavlenko (2012) has divided signage into three categories: official, commercial and private. While 'commercial' has been synonymous with 'private' (Laundry and Bourhis 1997), Pavlenko (2012) suggests that producers of commercial signs have only partial freedom of language choice because language choice in commercial signs is often regulated by law (Coupland 2012), which is the case in Slovakia. Thus, further refinement of the private category can be made: those devised for the public, as in this case, and those devised for a small circle of private persons. In the first case, the communication can be perceived to include both individual and community levels, whereas the second case offers limited insights beyond family language policy. 
The meaning of 'public' should be defined according to space too, as in Scollon and Scollon's model of geosemiotics (2003). The placement of private signs is typically at the gates and fences of private homes. Elsewhere in the public space, private inscriptions are often considered transgressions, a prototypical case of which is graffiti (Scollon and Scollon 2003). The investigated 'beware of the dog' signs then are private signs placed so that they are visible for the public eye.

Gal (2005) argues that categories such as public/private should not be seen dichotomous, but rather as existing along a continuum. Coupland (2012) stresses, that we should investigate how such terms as bottom-up/top-down are defined in the particular community. In Slovakia, commercial signs are regulated by law and controlled by inspections (Lanstyák \& Szabómihály 2009), while private signs are private in the sense of stemming from individual choice, although still bound by local practice and interpretation of language policy. Hence the 'beware of the dog' signs provide an excellent focus to examine the intersection between language ideologies, language policy and the LL. In this paper, I define private signs as voluntarily placed signs by private persons that are available for public view, horizontally addressing other private persons, and not for commercial purposes.

\section{The Sociopolitical and Legal Context of Hungarians in Slovakia}

According to the 2001 Slovak census, Hungarians form the majority in 410 villages and towns (Lanstyák and Szabómihály 2005). The areas inhabited by Hungarian speakers can be seen in the following map: 


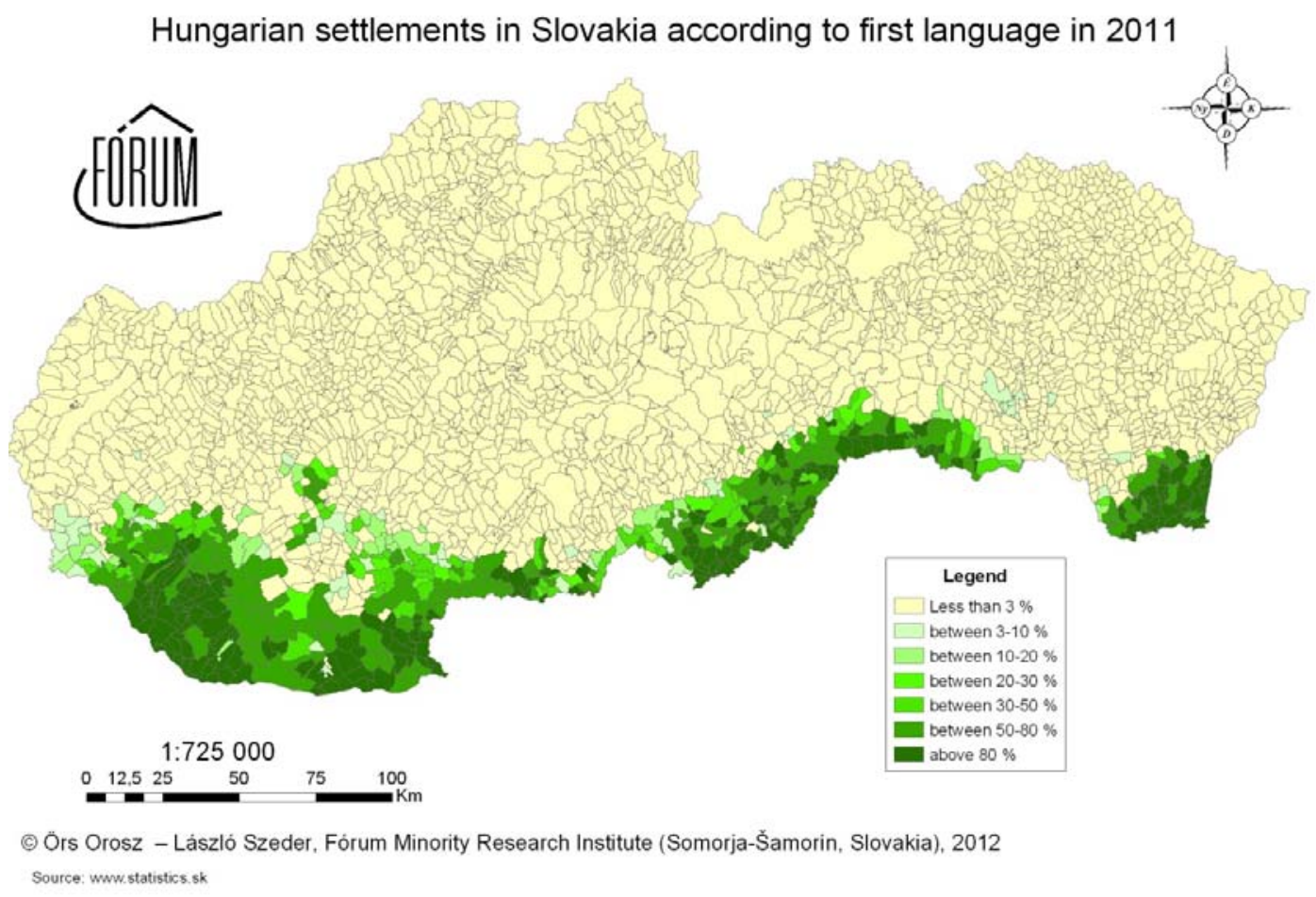

Language and the issue of the large Hungarian minority have been key topics of contention within the borders of the current republic of Slovakia (founded in 1993) since the treaty of Trianon (1920), which formed Czechoslovakia at the end of WWI. The current period, beginning with the 1990 transition from socialist system to democracy did not bring about a post-national period as in the western world (Heller 2011), but as Brubaker (2011) claims Slovakia, "appeared to be moving back to the nation-state, entering not a post-national but a post-multinational era” (p. 1786). The nationalist reign of Mečiar in the 1990's resulted in numerous linguistic conflicts stemming from changes in policies that affected contexts in which Hungarian had been routinely used (Szabómihály 2011). The issue which was most contested was the regulation in force between 1996-1999 that outlawed bilingual school certificates, it presented a rare case that mobilized the Hungarians as a community to fight for their right to use Hungarian in official contexts (Schwegler 2008).

In 1998, Mečiar lost the elections and Slovak moderates made some concessions to the Hungarian representatives, such as cancelling the above mentioned ban of school 
documentation in other languages than Slovak. A quick integration to Western alliances was followed by economic revival in the new millennium. For the Hungarian population the most burning problem has been the deep infrastructural and financial underdevelopment of the Hungarian region (Lanstyák and Szabómihály 2009). It is in this context, that the current study examines the nature of private signs for the purpose of understanding how such signs are reflective and indicative of future language policy. First, however a discussion of the legal situation pertaining to signage in these settlements during the time of the fieldwork will situate the study.

The sixth article of the constitution of Slovakia (1992) defines the Slovak language as the official language of the Slovak Republic. The Act on the State Language (1996), ${ }^{1}$ states that "The state language shall have priority over other languages" (Section 1(2)). Minority languages may be used in addition to the compulsory Slovak in specified domains and spaces (Third report 2012). The interpretation of the law on the part of Hungarians has often been stricter than what is stated in the law (Lanstyák and Langman 2000; Szabómihály 2011). Nonetheless, the essential focus of the law to make Slovak prevalent has continued. Changes in the Act on the State Language reflect the importance of language policy and perceptions of the importance of Slovak. For example, in 2009 a claim that many of the signs in public spaces in Southern Slovakia are in 'Hungarian only' was given as a basic reason for the need to further restrict the use of Hungarian through the Act. As a result of international monitoring, however a 'balancing' amendment was carried out in 2011, which for the first time made the use of minority languages compulsory in the special case of warning signs indicating "threats to life, health, security or property" (Third report 2012: 111). The leaflet 'Language rights in Slovakia' (Nyelvi jogok 2010), published in Hungarian by Hungarian language rights activists in Slovakia, gives the 'beware of the dog' signs as one example of

\footnotetext{
${ }^{1}$ English version: www.culture.gov.sk/posobnost-ministerstva/statny-jazyk/zakon-o-statnom-jazyku-c2.html (2 September 2013).
} 
information related to people's lives, health or safety that should be bilingual in the minority settlements, defined as those where Hungarians make up more than $20 \%$ of the population (Third report 2012). The message is presented in the text as well as in a cartoon showing a person posting a bilingual sign: 'beware of the dog' in Slovak and Hungarian. The cartoon emphasizes the importance of the sign type and thus gives it official flavor. The accompanying text first asks "whether there are signs that not only may, but must be in Hungarian, too" and then answers that warning signs indicating "threats to life, health, security or property" are signs that should be bilingual (Nyelvi jogok 2010: 23). This regulation is in general ignored; however, most warnings are typically in Slovak only in the Hungarian region (Laihonen 2015). Considering our case of "beware of the dog" signs, it is important to note that private persons cannot be fined for not following the Act, unlike entrepreneurs and institutions (Third report 2012), yet reference to the Act is common in many contexts (Langman and Lanstyák 2000; Szabómihály 2011).

\section{Method: A comparative case study of two villages}

The method employed here is a comparative case study of two villages drawing on ethnographic fieldwork techniques (Johnson 2013). I draw from ongoing fieldwork in Slovakia between 2010 and 2014. For this study, I chose two prototypical villages representing two ends of a demographic continuum; one bilingual and one with an overwhelming Hungarian majority (cf. Szabómihály and Lanstyák 2011). Selecting sites representative of different ends of the Hungarian majority continuum can provide insights on the connection between language policy, language ideologies and the LL. The core data for this study, a snapshot of the LL, were collected during a month of fieldwork, in November 2011. The LL was mapped through approximately one thousand photographs, supported by forty audio-recorded semi-open interviews which were carried out at villagers' homes. The 
planned themes of the semi-open interviews were issues of language use including opinions about using Hungarian in the public spaces. Most of the informants were Hungarian, but also included at least one Slovak and Roman family in each site. Since the word spread in the village that I was interviewing people, villagers sympathized with the interest in their lives and I received several spontaneous invitations to speak with people. My knowledge of Hungarian was instrumental in getting responses. Besides the photographs and interviews, many informal conversations were documented in fieldwork notes and locally produced materials such as flyers, notices, leaflets and local histories, were gathered as a way to deepen my understanding of the role of language in the villages.

The first step of the analysis aims to describe what languages are present in the LL and to what extent (Blommaert 2013). The LL in the two villages is presented first through descriptive statistics also to establish the distributional place of signs placed by private citizens among other signs in the LL. All signs in the 'public' space were counted. Signs inside institutions or houses, as well as inscriptions on gravestones were not considered 'public'. Further, due to the limited time and resources of fieldwork, identical signs were photographed only once. That is, a type versus token approach was used for data collection. A unit of quantitative analysis consisted of a text with all transparently coherent features; texts in texts, such as graffiti, were counted as separate texts.

A quantitative description is not capable of describing the semiotics of a chosen sign type or what meanings their design or placement conveys. Therefore, a second step in the analysis, a discourse analysis is applied to deliver interpretations of the "stories about the cultural, historical, political and social backgrounds of a certain space” (Blommaert 2013: 41). The discourse analysis (Hult 2009) focuses on the themes of semiotics, agency, language choice and underlying ideology behind the 'beware of the dog' signs. Moreover, 
consideration of the sociolinguistic markedness (Gal 1987) of the signs and sign types in Hungarian emerged through the discourse analysis of the interview data.

\section{Research sites: Two historical Hungarian villages in Southern Slovakia}

Reca $^{2}$ (Hungarian: Réte) is located 25 kilometres east of Bratislava, and is on the border region of Hungarian/Slovak population within Slovakia. In this region changes in the demographic and linguistic situation are rapid. Vásárút (Slovak: Trhová Hradská) is located in the midst of a Hungarian region 60 kilometres east of Bratislava, located in the Hungarian 'heartlands' a region characterised by more stability in terms of Hungarian language maintenance (Lanstyák and Szabómihály 2005).

Reca had an overwhelming majority of Hungarians (around $80 \%$ ) when it was ceded to Czechoslovakia in 1920. The population exchange with Hungary, forced through international pressure in 1946, removed the wealthier Hungarian families with no possibility of return, leaving a rural population with roughly 58\% Hungarian and 40\% Slovak (1970 census, Cséplő 1995). Since 1990 major changes in the community have resulted in growth as well as in a demographic shift, driven by the development of new housing. By 2011, the number of inhabitants has grown to 1378 , and the share of Hungarians has diminished to $37 \%$ (portal.statistics.sk 2013). Reca has both a Slovak and a Hungarian medium elementary school, the latter of which is on the verge of closing due to lack of students (Metzner 2000).

In contrast, Vásárút is quite Hungarian, with a population of 2,160 of whom $92 \%$ claimed Hungarian as their mother tongue in the 2011 census (portal.statistics.sk 2013). In comparison to other regions, relatively little emigration inside Slovakia or to other countries has taken place since the transition. Vásárút has a robust Hungarian school and no Slovak school (Presinszky 2002).

\footnotetext{
${ }^{2}$ I use the place names in the language of the 2011 majority in the given settlement.
} 


\section{Findings: A distributional sketch of the general $L L$ in the villages}

I begin the results by comparing the demographic makeup of the villages with the distribution of language choice in all signs. The distribution of the villagers according to first languages is based on the 2011 census $^{3}$; this is shown in Graphs 1-2.

Graphs 1-2 2011 census data (first language, portal.statistics.sk)
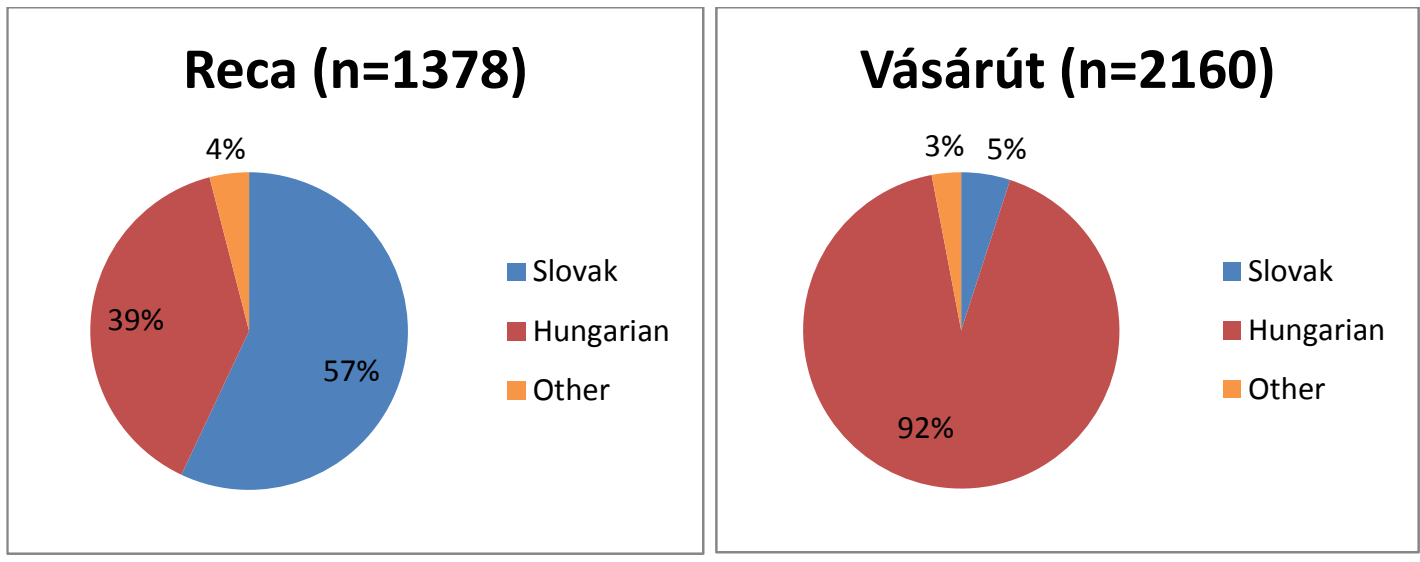

The distribution of language choice in the LL collected for this study is represented in graphs 3-4:

Graphs 3-4 Languages in public signs (\%)
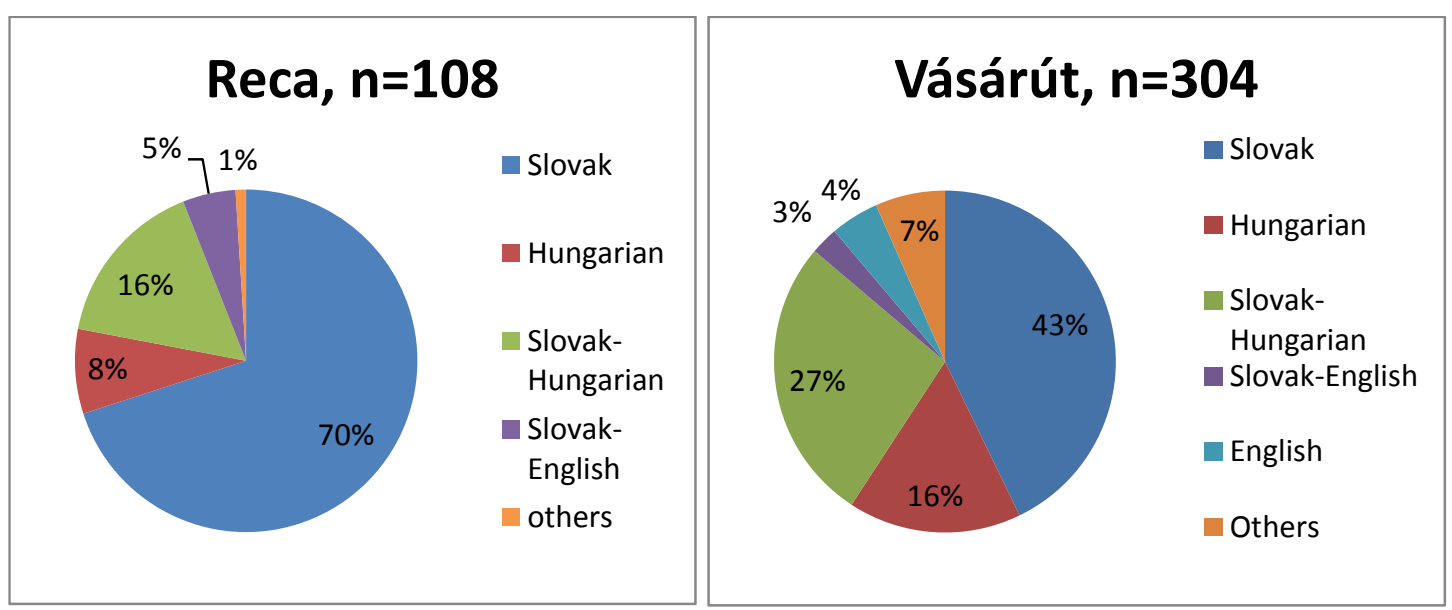

\footnotetext{
${ }^{3}$ Censuses should be accepted with caution as this Slovak census for example does not give information on bilingualism, which characterizes especially Reca.
} 
The languages in the LL include Slovak, Hungarian, English, Italian, Latin, German, French and Czech. The difference between the villages' ethnic composition is clearly reflected in their LLs. Reca, the bilingual community, has a smaller presence of Hungarian in public signs. For Reca the census shows 39\% of inhabitants claim Hungarian mother tongue, however, only $24 \%$ of signs include Hungarian. In the case of Vásárút it is even more obvious that the numbers display difference in the status of the languages. Vásárút has $5 \%$ inhabitants who claim Slovak as their mother tongue, but $42.8 \%$ of the signs are in Slovak only. Slovak monolingualism is frequent in the LL, bilingualism characterizes only one-third of the signs even in Vásárút. In both villages, Hungarian is most often used in bilingual texts, where a Hungarian text appears after or below a Slovak text.

Almost exclusively, the municipality represents Slovak-Hungarian bilingualism in Reca. The church and civil organizations, which are Hungarian dominant in their oral communication, produce the small number of monolingual Hungarian inscriptions while the commercial signs in Reca are in Slovak. In Vásárút, in contrast, bilingual commercial signs can also be found. These tendencies are accompanied by occasional ad hoc, hand-written, commercial signs (e.g. daily offers) in Hungarian and with a preference for naming bars, cafes and shops in English and Italian. Following the spirit and letter of law, signs pointing to non-local phenomena, such as transportation (e.g. road signs pointing to other settlements, signs in railroad stops etc.), communication (e.g. signs at post offices and mailboxes) and state or international contexts (e.g. signs of EU funding) are presented in Slovak only.

\section{Private signs in public places}

Private signs make up $13.8 \%$ of all signs. This number is notable especially given Pietikäinen et al.'s (2011) finding that the number of private signs was insignificant in their investigation 
of seven minority villages (Sámi, Kven and Meänkieli) in the Arctic region called North Calotte.

The signs in the private category in this study consisted of self-made advertisements or writings on the doors or walls, including graffiti. There were also stickers, notices and mailboxes, that have been manufactured industrially, but which have been hung or nailed in visible places. The distribution of private signs according to language is shown in the graphs 5 and 6 :

Graphs 5-6 Language choice in private signs

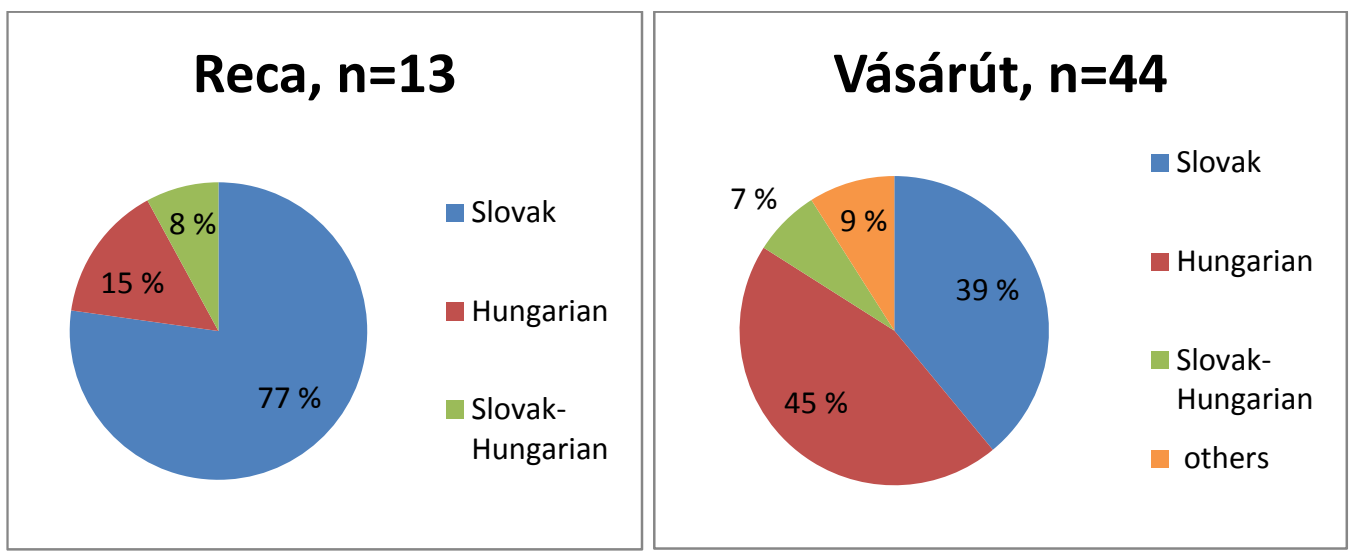

The private LL is significantly different from the general picture. For example, Reca has more monolingual Slovak signs in the private sphere. In Reca, most villagers stated in the interviews that bilingual signage would be ideal, but at the same time, respondents outlined that it is most important to avoid problems and not to "provoke" by taking a pro-Hungarian stand in the form of displaying Hungarian in public.

Language choice on private signs is similar to that of commercial signs, with the exception that there are fewer bilingual signs. In Reca they are mostly Slovak, whereas in Vásárút, Hungarian monolingual signs have a slight majority. However, as a methodological 
note, several of the Hungarian signs appear only once, whereas the most frequent Slovak 'beware of the dog' sign can be found practically in every street.

\section{Beware of the dog!}

The 'beware of the dog' is the most frequent private sign represented in the data (see Laihonen 2014 for a discussion of other private signs). In Reca, there are eight different and in Vásárút seventeen different 'beware of the dog' signs. This private sign has spread widely after the political transition in 1990. As I will show, in spite of the small number, the use of Hungarian in these signs is considered marked by participants in the study. The prevalence of 'beware of the dog!' signs is tied to the role of dogs in the context of these villages where dogs serve primarily as guards, not as pets, as in the Western World; hence the need to communicate to a visitor whether there is a dog in the yard or not. Even though the villagers know each other quite well, 'dog issues' are treated quite cautiously. During my fieldwork, for example, I was often accompanied by a local guide and it was always a topic of discussion whether there was a dog or not, and how to communicate in advance that we were coming - by phoning or shouting from the gate.

Reca: In Reca, the distribution of signs included a large numbers of manufactured signs for the purpose of warning as can be seen in Figures 1 and 2:
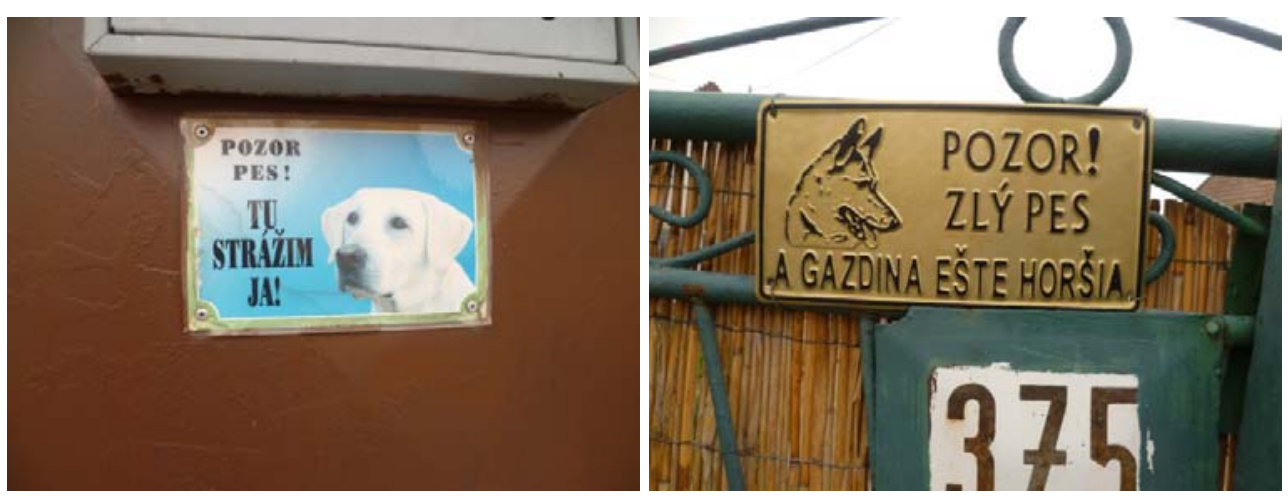
Fig. 1-2 "Beware of the dog” signs in Slovak, Reca (bilingual village)

The photographs in Figures 1 and 2 display typical 'beware of the dog' signs. They are manufactured, and have a warning text in Slovak, together with a picture of a dog. Following Kress and van Leeuwen (2006), both the verbal text and the visual component of the sign carry independent messages. An image of a dog on a fence or gate in a village house has the prototypical meaning "beware of the dog". However, the explicit verbal warnings, even though 'redundant', are still the most frequent textual elements of all such signs. Typically the images are neither controlled nor policed, whereas the verbal text is "rigorously controlled and codified" (Kress and van Leeuwen 2006: 26-27), and a language has to be chosen to establish an authoritative reading and code.

Here the warning inscription combined with language choice point to the potential addressees in many ways. First, the warnings can be seen as directed towards expected visitors indicating that they should wait at the gate to be safely let in. Thus, the language choice might be based on the assumed visitor's preference and the house owner's social networks. Secondly, the warning can be intended to keep away potential burglars and trespassers. Thus people might place such signs even though there is no dog. In the villages safety was in general considered good, although people reported in interviews, that there was some theft from gardens by people routinely referred to as "Gypsies". The Roma in the villages spoke both fluent Hungarian and Slovak, thus language choice seems not to be influenced by this imagined group of addressees. Thirdly, as was mentioned by informants the warnings are posted in order to avoid responsibility if the dog actually bites a visitor. According to both dominant and local language ideologies, from the point of view of being officially recognized, an inscription should be in Slovak or bilingual. Fourthly, sign language choice can be compared with the language choice for communication with unfamiliar people. 
In Reca, I was always greeted and addressed in Slovak by villagers I met on the streets, which shows that it was the default language for communicating with strangers.

The examples in Figures 1-2 above are typical of new signs sold in the capitalist economy. That is, beyond a warning, they also have a humorous remark ('I guard here!' in Figure 1 and 'The housewife is even worse' in Figure 2). Following Kress and van Leeuwen (2006), the remark 'I guard here' shows that the interaction between the producer of a sign with the addressee is typically carried out through an imagined character. In this case a dog addresses the viewer. Whereas, in the joke 'The housewife is even worse' we actually find the male owner of the sign addressing the viewer. These signs can be seen not only to warn and demarcate the space behind them, but through the humorous remarks also to display the dog owner's identity as an easy-going person. That is, they are ambiguous, containing both serious and humorous elements, and thus mitigate the threat to the addressee's face.

According to the informants, such signs have become popular in the last two decades, and they are available in shopping centers at a nearby Slovak town. Bilingual signs or signs in Hungarian are not available in the new international supermarket chains in Slovakia.

Reca's inhabitants promote bilingual signs in their accounts on private signage, "so that everybody would understand them", as many informants put it. However, this ideology is not transmitted to real life practices. The only bilingual sign in Reca is an old sign. It says: POZOR! ZLÝ PES and VIGYÁZZ! A KUTYA HARAP ('Beware! The dog bites!') The visual semiotics of the only bilingual sign - black text on a white background and the lack of an image of a dog - categorizes it as outdated, similar to the socialist bilingual inscriptions awaiting removal in Reca (e.g. 'with culture for peace' at a cultural center). Upon asking the villagers about this sign they were puzzled by its placement. "But he is not a very Hungarian person", they reacted. In other words, the sign was out of place since such a display of 
Hungarian identity is seen as a marked activity, given the norm in Reca to use Slovak on private signs.

This bilingual sign will be most likely the last of its kind. Blommaert (2013) has analyzed a sign that is the first of its kind in language choice as a token of important change. In Blommaert's case it demarcates an autonomous public space for a new language and community, consisting of the producer and the potential viewers of the sign. In our case, the last sign indicates the fading out of Hungarian and bilingual signs and their replacement with a uniformly monolingual Slovak sign.

Pietikäinen et al. (2011) investigate formerly destabilized Finno-Ugric (Sámi, Kven and Meänkieli) minority communities in Northern Scandinavia that are now supported by a dominant ideology of minority language revitalization. However, in the seven villages now claiming minority language in other arenas, all the private signs examined were in the majority language (Pietikäinen et al. 2011). Similarly, the use of Slovak only in private signage has been normalized in this formerly Hungarian majority village, where $39 \%$ of residents still claim Hungarian as their mother tongue.

Vásárút: Although Slovak 'beware of the dog' signs can be found in the Hungarian dominant Vásárút, the most notable feature in comparison to Reca is the presence of Hungarian commercially produced signs. The Hungarian signs were spread rather evenly in the village; there were no streets with a distinct 'Slovak' or 'Hungarian' character. According to informants, Hungarian monolingual signs have been purchased in Hungary, perhaps in the nearby town, Győr, where some villagers drive weekly for shopping. Among the manufactured Hungarian 'beware of the dog' signs in Vásárút, there was one sign that contained a longer narrative in Hungarian: 'If you hate violence, do not enter without ringing the bell! If you have already rung the bell, wait for my master. In the opposite case, ask your 
family doctor or your surgeon friend about potential side effects!' This narrative is a strong warning, since there is a threat of serious violence if the addressee ignores the sign. However, humor is indicated through the use of different stereotypical text genres, such as "if you hate violence", which is generally used for television, games etc. where a person, who does not like to "see violence", is warned. Another genre mixed here with an ironic effect is "ask your doctor about potential side effects", which typically refers to drugs. Here the latter is exaggerated: "ask your family doctor or surgeon friend", not many people in the Hungarian dominant village have surgeon friends, as such education is unavailable in Hungarian and the few doctors working in the village are Slovak first language speakers. The ambivalence of the seriousness of the narrative makes it humorous. This kind of humorous story or joke through the 'beware of the dog' signs is done only in Hungarian in Vásárút.

In the Hungarian dominant Vásárút, we find only two expressions in Slovak; either 'I guard here!' or the more standard 'beware of the dog' explicit warnings. Hult (2009) finds that language choice in commercial signs is often influenced by whether the passage is used to communicate information on what is being sold or whether it is used for symbolic meanings such as the notion of foreignness. In a similar vein, in the case of 'beware of the dog' signs in Vásárút, where bilingual signs are absent, only Hungarian is used for inscriptions that carry a humorous narrative or expression. The humorous expressions in turn can be seen to serve the purpose of mitigating the face threatening warnings. In the case of Vásárút addressees in all such cases are Hungarian speakers. Put the other way round, in Hungarian dominant Vásárút, Slovak is used only to communicate information to outsiders but not to display interpersonal relationships. Manufactured 'beware of the dog' signs are available only in Slovak (or English) in Slovakia, those in Hungarian have been bought in Hungary. 


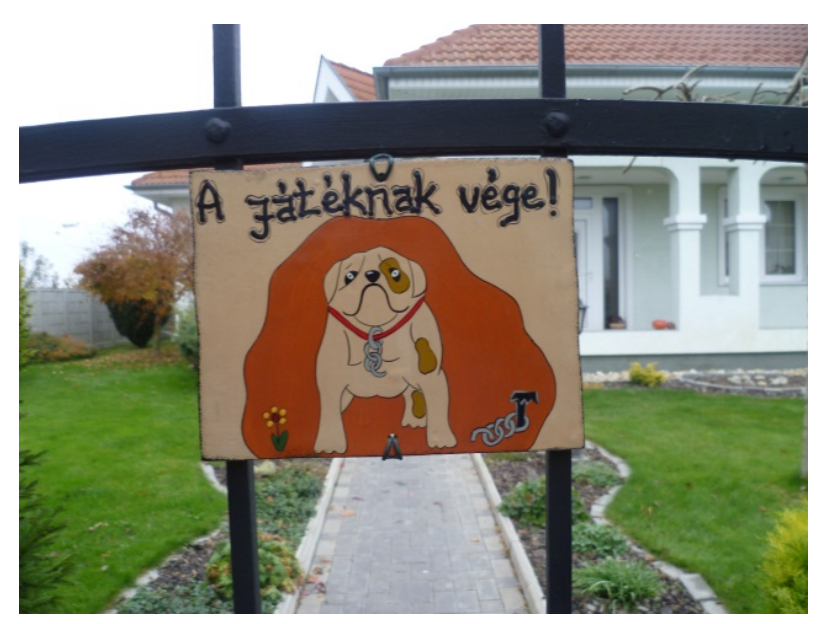

Fig. 3 'Game over!' in Hungarian, Vásárút (Hungarian dominant village)

The importance of humor as an interpersonal expression is further seen in Figure 3, which is serially produced and sold as a kind of a quasi handicraft. The text: 'game over' together with the picture where the dog has broken its chain and is now unleashed and will attack the intruder contributes to a multimodal narrative. In the picture, there are no other characters than the dog, which is looking at the reader, which in Scollon and Scollon's terms (2003) shows how the dog is narratively related to the passer-by. According to Kress and van Leeuwen (2006: 117-118), images with a character looking directly at the addressee's eyes establish a visual contact where the image is produced "to do something to the viewer". Here the watchdog can be seen to confront the addressee. The flower is part of the imaginary humor, which is accompanied by the 'game over' expression indexing the world of computer games. The monolingual use of Hungarian displays that the producer and the addressees are Hungarian speakers.

In Vásárút there is a community of Hungarian speakers, who do not consider the visual use of Hungarian in the private realm as taking a marked stand. In fact, in the interviews speakers may voice a negative stance towards 'nationalists' who demand the use 
of bilingual signs for local businesses. The interviewed Hungarians in Vásárút stated that they "do not want any trouble", but that they prefer Hungarian signage in the private sphere.

Since, "everybody speaks Hungarian here", they do not see any reason to produce signs in Slovak. This is a statement of resistance that is coupled by a sense of village life being part of 'private' rather than 'public' Slovak life, pointing toward a complicated minority ideology.

\section{Self-made signs}

While Figure 3 represents a sign with a humorous intent, handmade signs mimic the manufactured ones in terms of elements, with a similar shift in language to Hungarian.

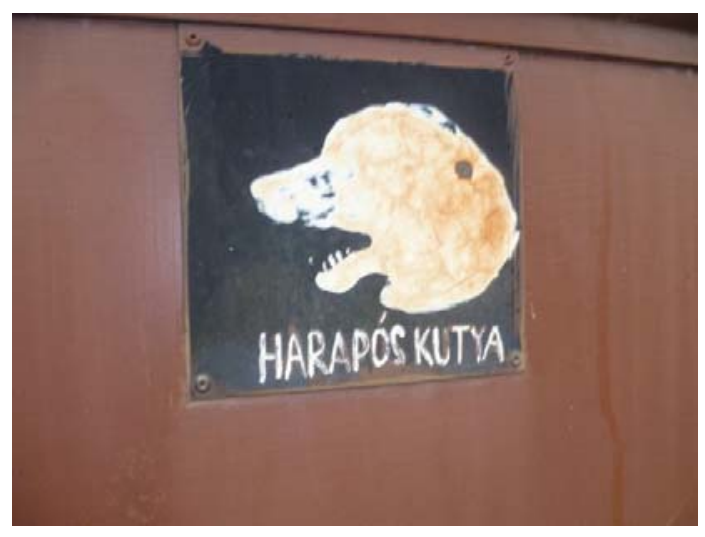

Fig. 4 'The dog bites’ in Hungarian, Vásárút (Hungarian dominant village)

This sign has the same elements as the manufactured ones, that is, an image of a dog in profile and a warning text. The humorous elements are missing from this sign. For language choice, self-made signs such as this have more freedom of choice, since they are not constrained by the supply of signs available in the given language. Also in the case of commercial signs, self-made inscriptions, such as daily offers are most likely to be in Hungarian in the villages with an overwhelming Hungarian majority (Laihonen 2015). 
This being said, there are self-made signs with Slovak inscriptions placed by ethnic Hungarians in the Vásárút's Hungarian dominant village, too. There is even a text POZOR PES with no image of a dog hand-carved to a small metal plate in Slovak only, hanging in front of the opening in a gate of a private home. The person placing this sign was referred to as a local Hungarian who used only Hungarian for everyday spoken communication in the village. A private sign in Slovak, placed by a Hungarian speaker in a practically monolingual Hungarian village might indicate that the ideology behind them is that warnings should be in Slovak. Such a text lacks the humorous element, so it can be seen to rather deliver a warning than a display of identity. A local colleague, István Lanstyák, who found this a general practice in bilingual settlements, offered a further explanation for hand-making Slovak private texts in a Hungarian village. As an example Lanstyák told a story about his neighbor, who was a Hungarian lady. She always spoke Hungarian with her neighbors, who were also Hungarians. However, once she had to leave a written message to Lanstyák, which she did in Slovak. Lanstyák explained that Hungarians in Slovakia rarely write anything in Hungarian since they might feel insecure in writing Hungarian and hence stick to Slovak for written inscriptions, even when private.

\section{Special cases}

As previously shown, the image of a dog is not compulsory for this sign type. However, the warning text is not compulsory either. The image of the dog, if placed on the gate or fence of the house, itself carries the meaning 'beware of the dog', which was a case in the Hungarian dominant Vásárút for one sign with a photograph of two black dogs placed on the fence of a house. That sign can be seen as an example of how to avoid the trouble of language choice and still communicate a warning. That is, as Kress and van Leeuwen (2006) established, a viewer of a sign without a verbal text can interpret it in different ways and in different 
languages. The inclusion of an inscription regulates the language choice of image interpretation as well. Thus, it is already a basic language ideological question whether a verbal text should be used at all. However, in this case the unusualness of the naturalistic photograph without the explicit threatening inscription also mitigates the message of threatening dogs. A similar case can be detected in the appearance of statues without inscriptions in the region (Laihonen 2015).

Conversely, the 'beware of the dog' signs may be accompanied with other sign types, such as mailboxes:

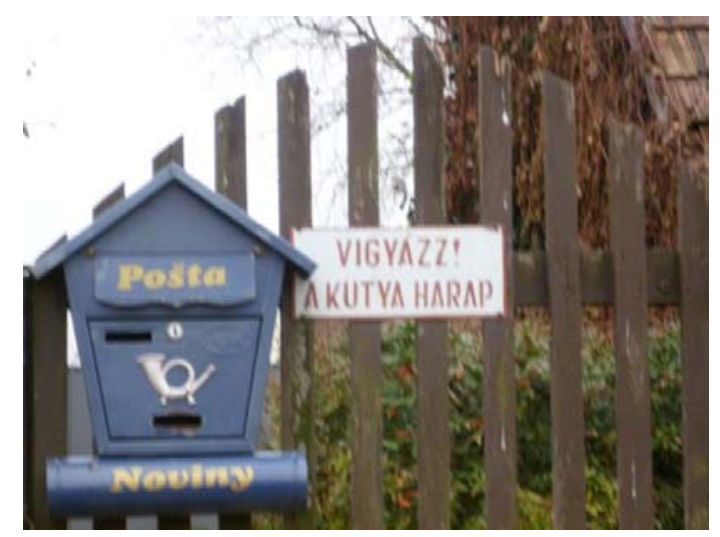

Fig. 5 mailbox in Slovak, 'dog bites’ in Hungarian, Vásárút (Hungarian dominant village)

This is a rare example of a monolingual Hungarian sign consisting of a text only. That is, in the lack of a universal image of a dog, this sign communicates the warning only for those who know Hungarian in the Hungarian dominant Vásárút, stating 'Beware, the dog bites.' In this case, Slovak monolinguals are excluded from the communication.

Figure 5 illustrates also the tendency that mailboxes are less likely to contain Hungarian inscriptions than the 'beware of the dog' signs. The national post is one of the emblematic symbols of European nation states. Accordingly, due to internal regulation, the use of Hungarian inscriptions is prohibited in the offices and mailboxes of the Slovak Post. Most houses have mailboxes, which are sold in the local post offices. Most of the mailboxes 
in the Hungarian dominant Vásárút had Slovak inscriptions. Still, there were two hand-made Hungarian "post" signs in Vásárút, indicating that even in this category some people make an effort to use Hungarian against the majority language ideology and policy. I interviewed a villager who explained with pride how he had created a Hungarian mailbox out of a standard mailbox with Slovak inscriptions. That is, the hand-made Hungarian mailboxes are transparently and consciously used to contest language use in Slovakia and to highlight a local Hungarian identity. While rare and subtle, this suggests that the 'beware of the dog signs' also indicate resistance to the dominant ideology and the expression of a Hungarian identity.

\section{Discussion}

The sale of 'beware of the dog' signs has met a significant demand in the villages which are now participating in global consumerism. Most of the signs photographed in this study are new in comparison to the socialist era when manufactured signs were not so easily available and there were more self-made signs. In the socialist period Hungarian had its share in the commercial and private LL even in Reca. Since then, handmade signs and bilingual signs have disappeared from Reca. A language policy analysis suggests that first, the postmultinational (Brubaker 2011) context in the new state, Slovakia, engaged in nation building, disfavors the public use of Hungarian. Second, the transition from a socialist economy to late capitalism (Heller 2011) has enhanced, or even escalated this process, since the global retailers have no interest in producing or delivering such commodities separately for the small ( $9 \%$ of the population) Hungarian community. In contemporary Slovakia, Slovak is perceived as the language for progress in the society, politics, education and economy; apparently there is no market for the use of Hungarian in Slovakia. Thus, in the bilingual Reca, it would be interpreted as transmitting a radical Hungarian stand to put a Hungarian 
'beware of the dog' sign on display, and even a bilingual sign would be interpreted as taking a clear pro-Hungarian stand.

The same kind of ideologies and practices in favor of using Slovak are present in Vásárút, too, and people have had to make choices while purchasing or producing signs in Hungarian. The counter-normativity of having monolingual Hungarian signs has been underlined by the language laws, which have put such an emphasis on warning signs, as well as the language rights leaflet (Nyelvi jogok 2010), which has elevated awareness of the 'beware of the dog' signs through a cartoon, as normatively bilingual. The commodity flows in Vásárút seem to give the people a choice to use either Slovak or Hungarian, but not the choice to purchase bilingual signs - as none are sold. Thus, for most it is far easier to purchase a Slovak sign, which is available in a shopping center in the next town, 7 kilometers from the village, in contrast to a journey of 45 kilometers to Györ across the border in Hungary. In interviews people mentioned other situations where language choice was reported as categorical: e.g. "we would never go to a movie in Slovak" or "we never buy newspapers in the supermarket" (no Hungarian newspapers are sold by international chains, whereas the local newspaper stands sell mostly newspapers in Hungarian). The case of the 'beware of the dog' signs is not categorical. However, due to the easier availability of the Slovak signs, and the potential threat to one's face of using Hungarian as a public visual language in Slovakia, it is remarkable that $52 \%$ of private signs include Hungarian. The proportion of private signs through the LL is significant as it is the only realm where a certain Hungarian dominance can be seen in both a quantitative and qualitative lens.

A basic ideology voiced in interviews in Vásárút is that Hungarian is to be used in the private sphere. In practice, however, the investigated 'beware of the dog' signs display both a commitment to the dominant ideology as well as resistance to it. Thus, they can be seen to have typical characteristics of both bottom-up and top-down flows of signs as seen in the 
presence of both Hungarian and Slovak monolingual hand-made private signs in the Hungarian dominant Vásárút. What is more, they point out that such categories as public/private or bottom-up/top-down are very relative and perhaps hide some significant details of a LL, namely the way people interpret the norms of visual language choice and use in spaces available for the public eye. However, it is just such interpretations and changes in language ideologies that indicate future language policies, minority language maintenance or language shift (cf. Gal 1987).

Hungarians have the most freedom of language choice in the public space in their private signage, while other areas of the LL are under strict control. In Slovakia the language laws regulate all public space, except that of private citizens. As Shohamy (2006) has noticed, private individuals often rely in their choice of language on general perceptions and considerations, which in this case means different and potentially competing local ideologies and practices of language choice. The results show that for private signage Vásárút is maintaining and potentially building a Hungarian identity, while Reca is reflecting a shift to the dominant Slovak identity.

The management of the investigated type of signs remains largely in the realm of simple language management (Nekvapil 2009). In other regions, we can experience successful campaigns and pressure on the commercial sector to produce and sell bilingual and monolingual signs in the historical minority language (Dal Negro 2009; Gorter, Aistaran and Cenoz 2012), but no such industry was in evidence in Slovakia or Hungary during the time of the fieldwork. In conclusion, private LL can be considered as tied to language policy on the ground as it represents a type of grass-roots activity reflecting resistance to real or perceived language laws strongly favoring Slovak monolingual signage. In this manner, the study demonstrates how reading a single type of sign, insignificant at first glance, can be closely connected to language policy on a larger scale. This study also shows the need to focus on 
smaller everyday practices, such as private visual language use, in order to understand the bigger picture of language policy. Indeed the recent work of Johnson (2013) and others indicate that more research utilizing ethnographic methods in language policy research is urgently needed.

Acknowledgments This research was financed by the Academy of Finland grant 137718. I cordially thank Mia Halonen, Juliet Langman, István Lanstyák, the Language Policy editor Elana Shohamy and the anonymous reviewers for their comments on earlier versions. Any remaining shortcomings are my sole responsibility.

\section{References}

Ben-Rafael, E., Shohamy E., Hasan Amara M. \& Trumper-Hecht N. (2006). Linguistic landscape as symbolic construction of the public space: The case of Israel. In D. Gorter (Ed.), Linguistic Landscape: A New Approach to Multilingualism (pp. 7-30). Clevedon: Multilingual Matters.

Blommaert, J. (2013). Ethnography, superdiversity and linguistic landscapes: Chronicles of complexity. Bristol: Multilingual Matters.

Brubaker, R. (2011). Nationalizing states revisited: projects and processes of nationalization in post-Soviet states. Ethnic and racial studies 34/11: 1785-1814.

Cséplö, F. (1995). Réte - bástya és menedék: Helytörténet két egyházi könyv köré építve. Gyorcsó István Alapítvány Füzetek 3.

Coupland, N. (2012). Bilingualism on display: The framing of Welsh and English in Welsh public places. Language in Society 41, 1-27.

Dal Negro, S. (2009). Local policy modeling the linguistic landscape. In E. Shohamy \& D. Gorter (Eds.) Linguistic Landscape: Expanding the Scenery (pp. 206-218). London: Routledge. 
Gal, S. (1987). Codeswitching and consciousness in the European periphery. American Ethnologist 14/4, 637-653.

Gal, S. (2005). Language ideologies compared: metaphors of public/private. Journal of Linguistic Anthropology 15/1, 23-37.

Gal, S. (2006). Language, its stakes and its effects. In R. Goodin \& Ch. Tilly (Eds). The Oxford Handbook of Contextual Political Analysis (pp. 376-391). Oxford: Oxford University Press.

Gorter, D., J. Aistaran \& J. Cenoz (2012). The revitalization of Basque and the Linguistic Landscape of Donostia-San Sebastián. In D. Gorter, H. Marten \& L. Van Mansel (Eds.) Minority Languages in the Linguistic Landscape (pp. 148-163). Basingstoke: Palgrave.

Heller, M. (2011). Paths to Post-Nationalism: A Critical Ethnography of Language and Identity. New York: Oxford University Press.

Huebner, T. (2009). A framework for the linguistic analysis of linguistic landscapes. In E. Shohamy \& D. Gorter (Eds.), Linguistic Landscape: Expanding the Scenery (pp. 88104). New York: Routledge.

Hult, F. (2009). Language ecology and linguistic landscape analysis. In E. Shohamy \& D. Gorter (Eds.). Linguistic Landscape: Expanding the Scenery (pp. 70-87). New York: Routledge.

Johnson, D. (2013). Language Policy. New York: Palgrave.

Kallen, J. (2009). Tourism and representation in the Irish linguistic landscape. In: E. Shohamy \& D. Gorter (Eds.), Linguistic Landscape: Expanding the Scenery (pp. 270284). New York: Routledge.

Kress, G. \& van Leeuwen, T. (2006). Reading Images: The Grammar of Visual Design. Second Edition. London: Routledge. 
Laihonen, P. (2014). Hungarian private linguistic landscape in South-West Slovakia. In J. Laakso (Ed.), Dangers and Developments: On Language Diversity in a Changing World: Studies in European Language Diversity 34: 85-105.

http://phaidra.univie.ac.at/o:369606 Accessed 18 January 2015.

Laihonen, P. (2015). Linguistic landscapes of a minoritized regional majority: Language ideologies among Hungarians in South-West Slovakia. In Laitinen, M \& A. Zabrodskaja (Eds.) Dimensions of Sociolinguistic Landscapes in Europe: Materials and Methodological Solutions (pp. 171-198). Frankfurt am Main: Peter Lang.

Landry, R. \& Bourhis, R. (1997). Linguistic landscape and ethnolinguistic vitality. Journal of Language and Social Psychology 16, 23-49.

Langman, J. \& Lanstyák, I. (2000). Language negotiations in Slovakia: Views from the Hungarian minority. Multilingua 19: 55-72.

Lanstyák, I. \& Szabómihály, G. (2005). Hungarian in Slovakia. In Fenyvesi, A. (Ed.) Hungarian Language Contact outside Hungary: Studies on Hungarian as a minority language (pp. 47-88). Amsterdam: John Benjamins.

Lanstyák, I. \& Szabómihály, G. (2009). Hungarian in Slovakia: language management in a bilingual minority community. In Nekvapil, J. \& T. Sherman (Eds). Language Management in Contact Situations: Perspectives from Three Continents (pp. 49-73). Frankfurt am Main: Peter Lang.

Metzner, V. (2000). Én iskolám, köszönöm neked: A magyar oktatás 50 éve Rétén. Dunaszerdahely: Csemadok Rétei Szervezete.

Nekvapil, J. (2009). The integrative potential of Language Management Theory. In J. Nekvapil \& T. Sherman (Eds), Language Management in Contact Situations: Perspectives from Three Continents (pp. 1-11). Frankfurt am Main: Peter Lang. 
Nyelvi jogok Szlovákiában: Anyanyelvhasználati útmutató (2010). Somorja: Fórum Kisebbségkutató Intézet.

Pavlenko, A. (2012). Transgression as the Norm: Russian in linguistic landscape of Kyiv, Ukraine. In: D. Gorter, H. Marten \& L. Van Mansel (Eds.) Minority Languages in the Linguistic Landscape (pp. 36-56). Basingstoke: Palgrave.

Pietikäinen, S., Lane, P., Salo, H. \& Laihiala-Kankainen, H. (2011). Frozen actions in Arctic linguistic landscape: A nexus analysis of language processes in visual space. International Journal of Multilingualism 8/4, 277-298.

Presinszky, L. (2002). Mit hagytak ránk a századok: Fejezetek Vásárút történelméböl. Somorja: FOTOS.

Schwegler, B. (2008). Confronting the Devil: Europe, Nationalism, and Municipal Governance in Slovakia. MS Dissertation. University of Chicago.

Scollon, R. \& Wong Scollon, S. (2003). Discourses in Place: Language in the Material World. London: Routledge.

Shohamy, E. (2006). Language Policy: Hidden agendas and new approaches. London: Routledge.

Shohamy, E. \& Abu Ghazleh-Mahajneh, M. (2012). Linguistic landscape as a tool for interpreting language vitality: Arabic as a 'minority' language in Israel. In D. Gorter, H. Marten \& L. Van Mansel (Eds.) Minority Languages in the Linguistic Landscape (pp. 89-108). Basingstoke: Palgrave.

Szabómihály, G. (2011). A szlovák nyelvpolitika és a nyelvhasználat jogi szabályozása Szlovákiában a rendszerváltozás után. In Szabómihály, G. \& I. Lanstyák (Eds.) Magyarok Szlovákiában VII. kötet. Nyelv (pp. 11-26). Somorja: Fórum Kisebbségkutató Intézet. 
Szabómihály, G. \& I. Lanstyák (eds. 2011). Magyarok Szlovákiában VII. kötet. Nyelv. Somorja: Fórum Kisebbségkutató Intézet.

Third Report on the Implementation of the European Charter for Regional or Minority Languages in the Slovak Republic (2012). www.coe.int/t/dg4/education/minlang/Report/PeriodicalReports/SlovakiaPR3_en.pdf. Accessed 22 April 2012.

Petteri Laihonen is a postdoctoral researcher at the Centre for Applied Language Studies and the Department of Languages, University of Jyväskylä, Finland. In 2011-2013 he held an Academy of Finland postdoctoral grant to study language ideologies among the Hungarian minorities from a comparative perspective. His publications deal with sociolinguistics, multilingualism, language ideologies, linguistic landscapes and language policy in Eastern Central Europe. His article Language Ideologies in Interviews: A Conversation Analysis Approach. Journal of Sociolinguistics (2008) developed a new approach for the qualitative analysis of research interviews. 